\title{
SISTEM INFORMASI SARANA DAN PRASARANA SESUAI STANDAR BAN-PT TERINTEGRASI SISFOKAMPUS 4.1
}

\author{
M. Ainul Yaqin, Syahiduzzaman, Imtihana \\ Teknik Informatika UIN Maulana Malik Ibrahim Malang
}

\begin{abstract}
Abstrak- Standar sarana dan prasarana adalah salah satu standar yang dinilai dalam instrumen BAN-PT, yaitu pada standar 6.2. Pengelolaan sarana dan prasarana sebuah perguruan tinggi harus memenuhi standar tersebut. Untuk dapat mengetahui seberapa besar tingkat pemenuhan standar diperlukan penilaian. Sistem informasi sarana dan prasarana yang dikembangkan dalam penelitian ini digunakan untuk memasukkan data-data usulan pengadaan, penerimaan, distribusi, penggunaan, pemeliharaan, dan pemusnahan. Laporan-laporan yang disajikan berbentuk tabel dan grafik yang menyatakan kinerja keuangan dan diukur sesuai dengan standar 6.2. BAN-PT. Sistem informasi sarana dan prasarana ini, juga terintegrasi dengan SISFOKAMPUS 4.1 yang merupakan sistem informasi akademik open source yang berbasis web. Hasil dari penelitian ini adalah sistem informasi sarana dan prasarana dengan fungsi khusus yaitu menilai kinerja keuangan yang sesuai dengan standar 6.1. BAN-PT yang dapat digunakan untuk melakukan audit internal.
\end{abstract}

Kata kunci : standar 6.2. BAN-PT, Sistem Informasi Sarana dan Prasarana, SISFOKAMPUS 4.1.

\section{PENDAHULUAN}

Sarana dan prasarana merupakan bagian penting dalam proses belajar mengajar di lembaga pendidikan. Hal ini tercantum dalam PP No.19 Tahun 2005 tentang Standar Nasional Pendidikan, pasal 1 ayat (8) mengemukakan bahwa standar sarana dan prasarana adalah standar nasional pendidikan yang berkaitan dengan kriteria minimal tentang ruang belajar, tempat olah raga, tempat beribadah, perpustakaan, laboratorium, bengkel kerja, tempat bermain, tempat berekreasi dan berkreasi, serta sumber belajar lain yang diperlukan untuk menunjang proses pembelajaran termasuk penggunaan teknologi informasi dan komunikasi.

Peran sistem informasi di lembaga pendidikan telah menjadi bagian penting dalam operasional kegiatan akademik. Salah satunya yaitu SisfoKampus yang telah diterapkan di Institut Agama Islam Ibrahimy Sukorejo Situbondo, akan tetapi SisfoKampus belum memiliki fitur untuk pengelolaan sarana dan prasarana, oleh karena itu perlu dikembangkan sistem informasi sarana dan prasarana yang terintegrasi dengan SisfoKampus

Integrasi sistem memiliki keuntungan dalam mempertahankan sistem yang sudah berjalan dan memberikan nilai lebih terhadap hal tersebut dengan mengintegrasikannya dengan aplikasi lain. Integrasi juga memungkinkan penambahan suatu fitur dari aplikasi yang sudah ada tanpa harus merombak total struktur aplikasi yang lama. Hal ini akan lebih hemat dari sisi biaya dan lebih menghemat waktu dari sisi development dibandingkan harus membuat sistem yang baru secara utuh.
Sistem informasi sarana dan prasarana diharapkan dapat membatu pengelolaan sarana dan prasarana agar lebih baik dan dapat mendukung upaya pencapaian peringkat akreditasi. Pencapaian akreditasi merupakan salah satu bentuk penilaian mutu dan kelayakan institusi perguruan tinggi atau program studi oleh Badan Akreditasi Nasional Perguruan Tinggi (BAN-PT). Standar akreditasi institusi perguruan tinggi tentang sarana dan prasarana terdapat dalam standar 6 BAN-PT.

Terdapat beberapa elemen penilaian terkait sarana dan prasarana dalam standar ini diantaranya yaitu sistem pengelolaan sarana dan prasarana, lokasi, status, penggunaan, dan luas lahan yang digunakan untuk kegiatan perguruan tinggi, data, bahan pustaka yang digunakan dalam proses pembelajaran, serta penyediaan sarana dan prasarana pembelajaran tingkat terpusat untuk mendukung interaksi akademik antara mahasiswa, dosen, pakar, dan nara sumber lainnya dalam kegiatan-kegiatan pembelajaran. Pengelolaan sarana dan prasarana perguruan tinggi meliputi perencanaan, pengadaan, penggunaan, pemeliharaan, pemutakhiran, inventarisasi, dan penghapusan aset yang dilakukan secara baik, sehingga efektif mendukung kegiatan penyelenggaraan akademik di perguruan tinggi. Elemen-elemen dalam standar inilah yang menjadi acuan dalam pembuatan sistem informasi sarana dan prasarana serta laporan sarana dan prasarana yang dihasilkan. 


\section{A. RUMUSAN MASALAH}

Rumusan masalah dalam penelitian ini adalah:

1. Bagaimana mengelola data sarana dan prasarana perguruan tinggi secara terkomputerisasi ?

2. Bagaimana mengintegrasikan sistem informasi sarana dan prasarana dengan Sisfokampus 4.1?

3. Bagaimana melaporkan dan menilai kinerja perguruan tinggi berdasarkan standar 6 BAN-PT ?

\section{B. HIPOTESIS}

Hipotesis dalam penelitian ini adalah

1. Dengan adanya sistem informasi keuangan ini, maka masalah-masalah yang terkait dengan pegelolaan sarana dan prasarana yang terkait dengan pengadaan, distribusi, penggunaan, pemeliharaan, dan pemusnahan dapat teratasi khususnya laporan kinerja keuangan yang sesuai dengan standar 6.1. BAN-PT.

2. Masalah integrasi sistem informasi sarana dan prasarana dengan SISFOKAMPUS 4.1 dapat dilakukan dengan mengakses tabel-tabel yang dibutuhkan dalam database SISFOKAMPUS 4.1 dan melengkapinya dengan tabel-tabel yang dibutuhkan dalam sistem informasi sarana dan prasarana.

3. Dengan adanya sistem informasi sarana dan prasarana ini, maka pelaporan dan penilaian kinerja sarana dan prasarana perguruan tinggi dapat diotomasikan.

\section{TUJUAN}

Tujuan penelitian ini adalah : Mengembangkan sistem informasi pengelolaan sarana dan prasarana yang terintegrasi dengan Sisfokampus 4.1. dengan pelaporan dan penilaian kinerja berdasarkan standar 6 BAN-PT.

\section{MANFAAT}

1. Pengelolaan data secara terkomputerisasi akan mengurangi biaya operasional.

2. Integritas data lebih terjamin

3. Pembagian hak akses secara tepat dalam sistem informasi akan memperjelas tanggung jawab dan kewenangan setiap orang.

4. Setiap saat dapat memantau kinerja sarana dan prasarana.

5. Integrasi dengan SISFOKAMPUS 4.1 membuat kerja lebih efisien, dan mengurangi beban kerja personil.

\section{SISTEM INFORMASI SARANA DAN PRASARANA}

Sistem informasi sarana dan prasarana merupakan sistem informasi berbasis web yang berfungsi untuk melakukan pendataan sarana dan prasarana. Pada umumnya sistem informasi sarana prasarana menangani pengolahan data sarana dan prasarana meliputi proses pengadaan, pendistribusian, opname, perbaikan hingga pemusnahan sarana dan prasarana. Proses awal yaitu pengajuan usulan pengadaan sarana dan prasarana, kemudian pemeriksaan dan penyimpnan barang yang telah diterima dari hasil pengadaan, pendistrbusian sarana dan prasarana ke gedung maupun ruang yang ada, opname sarana dan prasarana secara berkala, pengajuan usulan perbaikan terhadap sarana prasarana yang mengalami kerusakan serta pengajuan dan pengadaan pemusnahan.

Dari data-data tersebut menghasilkan laporan dan grafik. Laporan yang dihasilkan diantaranya laporan daftar sarana dan prasarana keseluruhan atau berdasarkan periode tertentu. Laporan mengenai pengadaan sarana prasarana, laporan pendistribusian sarana dan prasarana, laporan kondisi barang dari hasil opname, laporan perbaikan serta laporan penghapusan barang. Laporan dapat dicetak secara keseluruhan maupun berdasarkan tahun atau program studi tertentu.

\section{STANDAR BAN-PT}

Badan Akreditasi Nasional Perguruan Tinggi merupakan lembaga independen nonstruktural yang dibentuk oleh Menteri Pendidikan dan Kebudayaan pada tahun 1994 dengan tugas melakukan akreditasi terhadap perguruan tinggi. BAN-PT adalah lembaga yang memiliki kewenangan untuk mengevaluasi dan menilai, serta menetapkan status dan peringkat mutu institusi perguruan tinggi berdasarkan standar mutu yang telah ditetapkan.

Standar 6 BAN-PT tentang sarana dan prasarana, serta sistem informasi merupakan acuan keunggulan mutu pengadaan dan pengelolaan sarana dan prasarana yang diperlukan untuk penyelenggaraan program-program dalam perwujudan visi, penyelenggaraan misi, dan pencapaian tujuan perguruan tinggi. Dalam buku 2 dan buku 5 BAN-PT terdapat beberapa elemen penilaian yang berkaitan dengan sarana dan prasarana dalam standar 6 BAN-PT (Badan Akreditasi Nasional Perguruan Tinggi) yaitu:

a. Sistem pengelolaan sarana dan prasarana.

b. Lokasi, status, penggunaan, dan luas lahan yang digunakan untuk kegiatan perguruan tinggi.

c. Data prasarana (kantor, ruang kelas, laboratorium, dan studio, dan lain-lain). 
d. Bahan pustaka yang digunakan dalam proses pembelajaran.

e. Penyediaan sarana dan prasarana pembelajaran tingkat terpusat untuk mendukung interaksi akademik antara mahasiswa, dosen, pakar, dan nara sumber lainnya dalam kegiatan-kegiatan pembelajaran.

Pengelolaan sarana dan prasarana perguruan tinggi meliputi perencanaan, pengadaan, penggunaan, pemeliharaan, pemutakhiran, inventarisasi, dan penghapusan aset yang dilakukan secara baik, sehingga efektif mendukung kegiatan penyelenggaraan akademik di perguruan tinggi. Kepemilikan dan aksesibilitas sarana dan prasarana sangat penting untuk menjamin mutu penyelenggaraan akademik secara berkelanjutan.

\section{SISFOKAMPUS 4.1.}

SisfoKampus merupakan suatu sistem informasi terintegrasi yang digunakan untuk mempermudah perguruan tinggi dalam mendukung proses penyelenggaraan pendidikan tinggi berbasiskan Teknologi Informasi dan Komunikasi (TIK). SisfoKampus merupakan aplikasi berbasiskan web yang dapat diakses menggunakan web browser. Karena aplikasi ini bersifat deskstop services, maka pengguna (user) tidak perlu melakukan instalasi pada komputer miliknya, melainkan dapat mengakses secara remote dengan menggunakan fasilitas web browser yang dimiliki, tentunya dengan membangun koneksi dengan server (baik jaringan LAN maupun WAN) yang telah terinstall aplikasi SisfoKampus terlebih dahulu.

SisfoKampus merupakan nama sebuah kerangka kerja umum sistem informasi manajemen untuk perguruan tinggi di Indonesia. Beberapa laporan yang terdapat pada aplikasi SisfoKampus telah disesuaikan dengan kebutuhan institusi sehingga aplikasi SisfoKampus ini sudah dapat diterapkan (aplicable) dalam mendukung manajemen pendidikan tinggi berbasis TIK di perguruan tinggi. Dalam penelitian ini, sistem informasi sarana dan prasarana yang dibangun akan diintegrasikan dengan SisfoKampus 4.1. Sebagian data yang terdapat dalam database SisfoKampus memiliki peran penting dan keterkaitan dengan sistem informasi sarana prasarana sehingga integrasi keduanya perlu dilakukan. Data tersebut diantaranya adalah data ruang, prodi, fakultas, kampus, karyawan, dosen dan jadwal. 


\section{LINGKUP PROYEK}

Tabel 1. Lingkup Proyek

\begin{tabular}{|c|c|c|c|c|c|}
\hline $\begin{array}{l}\text { Hak Akses } \\
\text { Lingkup yang } \\
\text { Dikerjakan }\end{array}$ & Admininistrator & Ketua Jurusan & Staf Sarana Prasarana & $\begin{array}{c}\text { KaBag Sarana } \\
\text { Prasarana }\end{array}$ & Rektor \\
\hline Lingkup Data & $\begin{array}{l}\text { Data jadwal opname } \\
\text { Data lahan } \\
\text { Data gedung } \\
\text { Data ruang } \\
\text { Data barang } \\
\text { Data pustaka } \\
\text { Data karyawan } \\
\text { Data program studi }\end{array}$ & $\begin{array}{l}\text { Data pengadaan sesuai prodi } \\
\text { Data pengajuan distribusi } \\
\text { Data maintenance sesuai prodi } \\
\text { Data pemusnahan sesuai prodi } \\
\text { Data lahan } \\
\text { Data gedung } \\
\text { Data ruang } \\
\text { Data barang } \\
\text { Data pustaka } \\
\text { Data program studi }\end{array}$ & $\begin{array}{l}\text { Data Lahan } \\
\text { Data Gedung } \\
\text { Data Ruang } \\
\text { Data Barang } \\
\text { Data Pustaka } \\
\text { Data pengadaan sarana prasarana } \\
\text { Data distribusi sarana prasarana } \\
\text { Data opname sarana prasarana } \\
\text { Data maintenance } \\
\text { Data pemusnahan } \\
\text { Data jadwal perkuliahan }\end{array}$ & $\begin{array}{l}\text { Laporan pengadaan } \\
\text { Laporan distribusi } \\
\text { Laporan opname } \\
\text { Laporan maintenance } \\
\text { Laporan pemusnahan } \\
\text { Laporan Lahan } \\
\text { Laporan Bangunan } \\
\text { Laporan Ruang } \\
\text { Laporan Barang } \\
\text { Laporan Pustaka } \\
\text { Laporan standar } 6 \\
\end{array}$ & $\begin{array}{l}\text { Laporan pengadaan } \\
\text { Laporan distribusi } \\
\text { Laporan opname } \\
\text { Laporan maintenance } \\
\text { Laporan pemusnahan } \\
\text { Laporan Lahan } \\
\text { Laporan Bangunan } \\
\text { Laporan Ruang } \\
\text { Laporan Barang } \\
\text { Laporan Pustaka } \\
\text { Laporan standar } 6 \\
\end{array}$ \\
\hline Lingkup Proses & $\begin{array}{l}\text { Data karyawan, } \\
\text { program studi, ruang } \\
\text { untuk menyusun } \\
\text { jadwal opnane } \\
\text { Data lahan, } \\
\text { bangunan, ruang, } \\
\text { barang, pustaka untuk } \\
\text { pendataan sarana } \\
\text { prasarana }\end{array}$ & $\begin{array}{l}\text { Data sarana prasarana, ketua jurusan, } \\
\text { fakultas, prodi, gedung, ruang untuk } \\
\text { mengajukan usulan pengadaan. } \\
\text { Data sarana prasarana, ketua jurusan, } \\
\text { prodi untuk mengajukan usulan } \\
\text { maintenance. } \\
\text { Data sarana prasarana, ketua jurusan, } \\
\text { prodi, untuk mengajukan usulan } \\
\text { pemusnahan. }\end{array}$ & $\begin{array}{l}\text { Data sarana prasarana, prodi, untuk } \\
\text { pengecekan sarana prasarana yang telah } \\
\text { diadakan. } \\
\text { Data jadwal perkuliahan untuk } \\
\text { menghitung utilisasi sarana prasarana. } \\
\text { Data sarana prasarana, ruang, prodi } \\
\text { untuk pendistribusian. } \\
\text { Data sarana prasarana, ruang, prodi, } \\
\text { untuk opname sarana prasarana. } \\
\text { Data sarana prasarana untuk pengecekan } \\
\text { sarana prasarana setelah maintenance } \\
\text { Data sarana prasarana, ruang, prodi } \\
\text { untuk pengecekan pemusnahan. }\end{array}$ & & $\begin{array}{l}\text { Data usulan pengadaan untuk } \\
\text { validasi } \\
\text { Data usulan maintenance } \\
\text { untuk validasi } \\
\text { Data usulan pemusnahan } \\
\text { untuk validasi }\end{array}$ \\
\hline
\end{tabular}




\begin{tabular}{|c|c|c|c|c|c|}
\hline $\begin{array}{l}\text { Hak Akses } \\
\text { Lingkup yang } \\
\text { Dikerjakan }\end{array}$ & Admininistrator & Ketua Jurusan & Staf Sarana Prasarana & $\begin{array}{c}\text { KaBag Sarana } \\
\text { Prasarana }\end{array}$ & Rektor \\
\hline $\begin{array}{l}\text { Lingkup } \\
\text { komunikasi }\end{array}$ & $\begin{array}{l}\text { Hak akses ini } \\
\text { berwenang untuk } \\
\text { melakukan input, } \\
\text { update, dan delete } \\
\text { jadwal opname dan data } \\
\text { sarana prasarana yang } \\
\text { tidak melalui } \\
\text { pengadaan. }\end{array}$ & $\begin{array}{l}\text { Hak akses ini berwenang untuk melakukan } \\
\text { input, update, dan delete data usulan } \\
\text { pengadaan, distribusi, maintenance dan } \\
\text { pemusnahan. Sedangkan untuk data sarana } \\
\text { prasarana hanya untuk view. }\end{array}$ & $\begin{array}{l}\text { - Hak akses ini berwenang untuk } \\
\text { melakukan input, update, dan delete data } \\
\text { distribusi dan opname. } \\
\text { - Dan berwenang untuk update data } \\
\text { pengadaan, maintenance dan } \\
\text { pemusnahan. } \\
\text { - Sedangkan untuk data sarana prasarana } \\
\text { hanya untuk view. }\end{array}$ & $\begin{array}{l}\text { Hak akses ini hanya } \\
\text { berwenang untuk } \\
\text { melakukan print out } \\
\text { data dan laporan. }\end{array}$ & $\begin{array}{l}\text { Hak akses ini berwenang } \\
\text { untuk validasi usulan } \\
\text { pengadaan, maintenance dan } \\
\text { pemusnahan sarana prasarana } \\
\text { serta melakukan print out } \\
\text { laporan. }\end{array}$ \\
\hline
\end{tabular}




\section{SITEMAP APLIKASI}

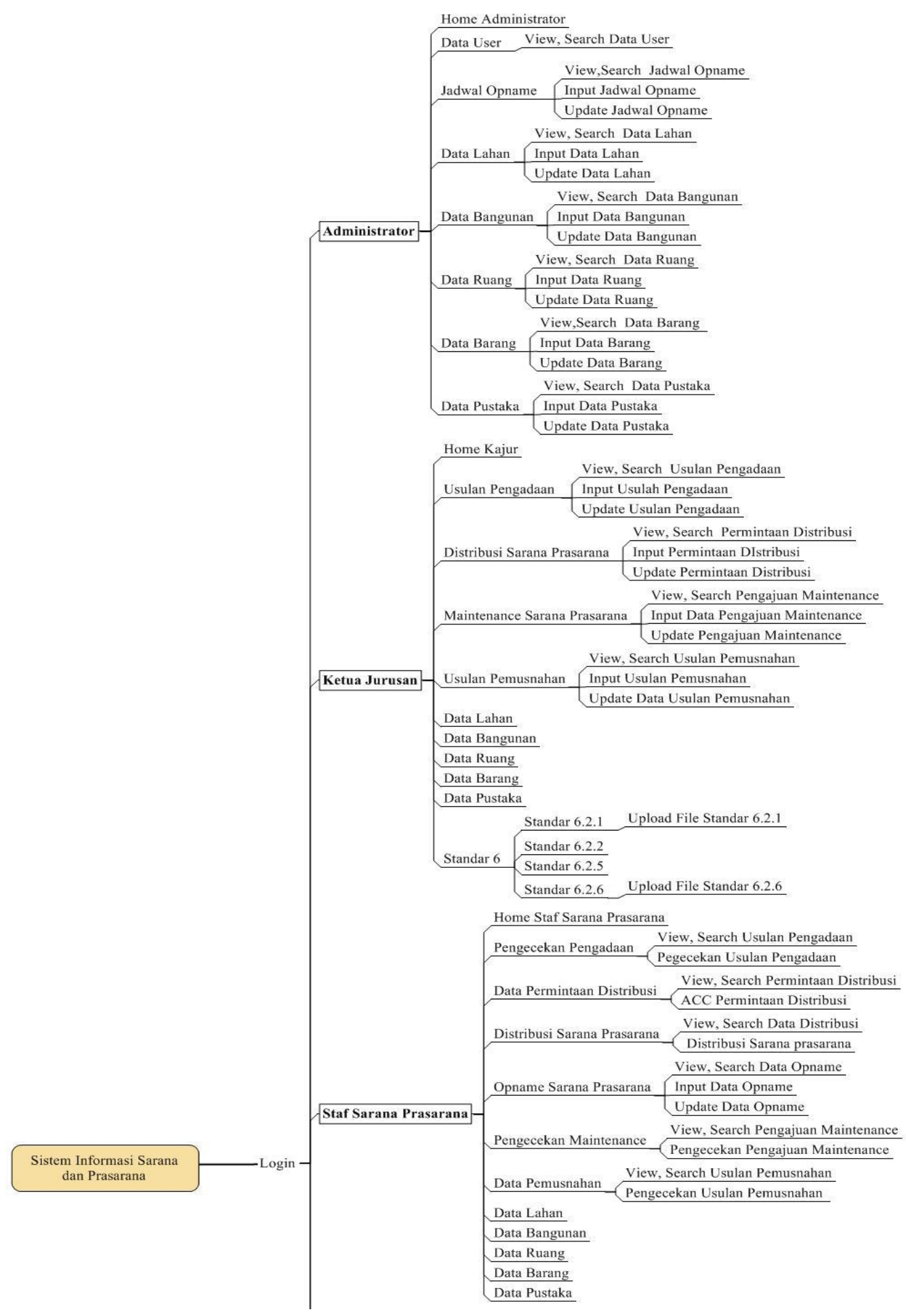




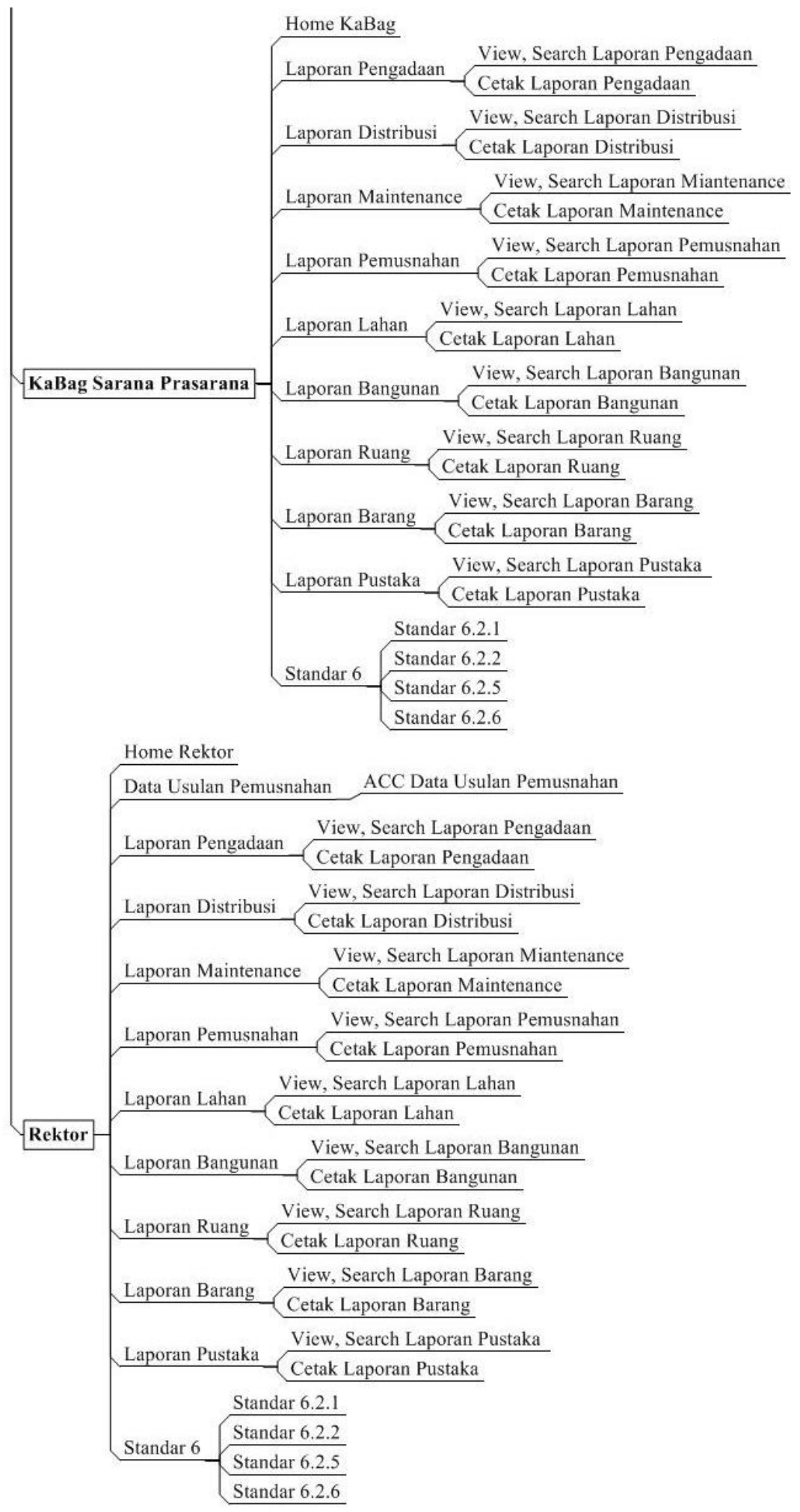

Gambar 1. Sitemap aplikasi 


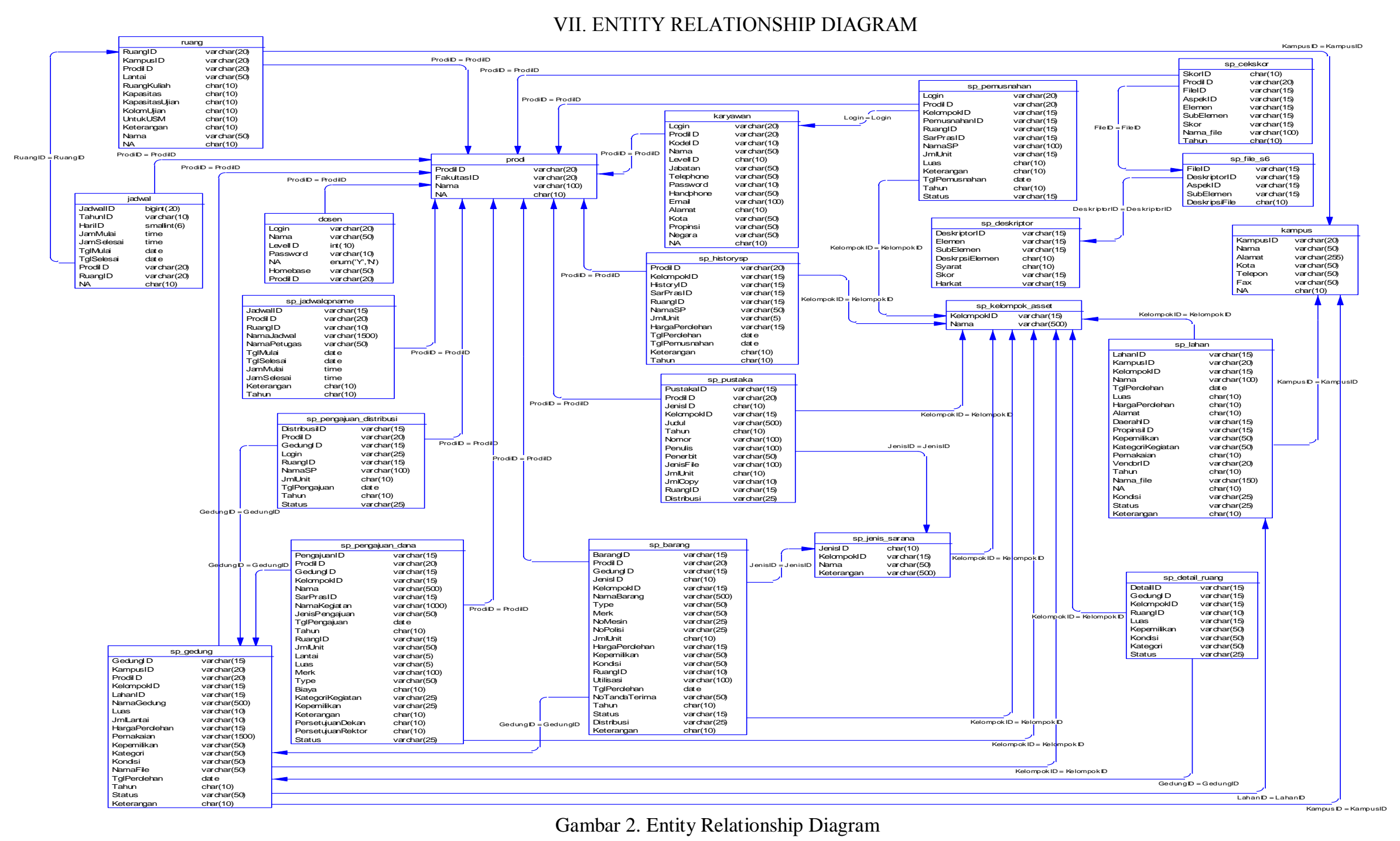




\section{HASIL DAN PEMBAHASAN}

Berdasarkan pengujian yang telah dilakukan oleh programer melalui pengujian alfa dengan metode blackbox testing, dari total item pengujian sebanyak 25, diperoleh hasil pengujian dengan prosentase $88 \%$ untuk nilai S (Sesuai) dan $12 \%$ untuk nilai TS (Tidak Sesuai). Nilai S (Sesuai) menyatakan bahwa pengujian yang dilakukan hasilnya sesuai dengan standar pengujian. Sedangkan pada hasil TS (Tidak Sesuai) ketika dilakukan pengujian terdapat beberapa hasil output yang masih belum sesuai dengan standar pengujian.

Hasil dari penelitian ini adalah Sistem Informasi Sarana dan Prasarana yang terintegrasi dengan SISFOKAMPUS 4.1. Sistem informasi sarana dan prasarana yang dikembangkan ini memiliki beberapa fitur yaitu :

- Terintegrasi dengan SISFOKAMPUS 4.1. sehingga data-data akademik yang terkait dengan sarana dan prasarana dapat langsung diakses dan diolah menurut keperluannya. Data-data tersebut adalah : data gedung dan ruang yang terkait dengan penggunaannya dalam kegiatan perkuliahan, data alat-alat laboratorium yang terkait pengguanaannya dalam kegiatan penelitian dan praktikum.

- Sistem informasi sarana dan prasarana ini disesuaikan dengan proses pengelolaan sarana dan prasarana secara umum, mulai dari pengusulan pengadaan hingga pemusnahan. Proses pengadaan tidak dibahas dalam penelitian ini.

- Standar 6.2. BAN-PT yang mengatur masalah kinerja sarana dan prasarana juga diadopsi oleh sistem informasi sarana dan prasarana ini sebagai kontrol dan audit internal bagi perguruan tinggi yang menggunakannya.

Dengan demikian dapat dikatakan bahwa proses bisnis pengelolaan sarana dan prasarana yang ada dalam suatu perguruan tinggi dapat dilayani oleh sistem informasi sarana dan prasarana ini.

SISFOKAMPUS 4.1 digunakan sebagai dasar bagi pengembangan sistem informasi yang lainnya, hal ini disebabkan oleh SISFOKAMPUS 4.1 adalah sistem informasi yang melayani berlangsungnya sistem akademik dalam perguruan tinggi. Dari sistem akademik tersebut kemudian berkembang menjadi berbagai macam kebutuhan sistem informasi, salah satunya adalah masalah sarana dan prasarana. Dalam penelitian ini berhasil dilakukan integrasi antara sistem informasi sarana dan prasarana dengan SISFOKAMPUS 4.1. Integrasi dilakukan pada bagian database, yaitu dengan mengakses tabel-tabel yang diperlukan untuk pengolahan data sarana dan prasarana dan menambahkan tabel-tabel baru yang belum ada di dalam database SISFOKAMPUS 4.1. Integrasi antara kedua sistem informasi ini telah berhasil dilakukan.

Penerapan standar 6.2. BAN-PT dalam sistem informasi sarana dan prasarana sebagai aturan dalam penilaian kinerja sarana dan prasarana dan tata cara pelaporannya. Fitur ini sangat berguna untuk mengetahui kinerja sarana dan prasarana dari perguruan tinggi yang menggunakannya. Dari nilai kinerja tersebut kemudian dapat digunakan oleh pengambil keputusan sebagai dasar dalam mengambil keputusan atau kebijakan yang terkait dengan sarana dan prasarana.

\section{KESIMPULAN}

Dari hasil penelitian yang telah dilakukan dan pembahasan Sistem Informasi Sarana dan Prasarana berbasis web, diperoleh kesimpulan sebagai berikut:

1. Sistem informasi sarana dan prasarana memudahkan pendataan sarana prasarana, serta pencatatan data distribusi, opname, maintenance dan pemusnahan.

2. Sistem informasi sarana dan prasarana terintegrasi dengan SisfoKampus 4.1 melalui penggunaan data yang diambil dari beberapa tabel pada SisfoKampus 4.1.

3. Sistem informasi sarana dan prasarana dapat menghasilkan laporan tahunan dan laporan sesuai prodi serta menampilkan skor standar 6.2.1, 6.2.2, 6.2.5 dan 6.26 disertai cetak laporan.

Hasil pengujian alfa dengan metode blackbox testing pada sistem informasi sarana dan prasarana yang telah dibuat menyatakan $88 \%$ sesuai standar pengujian dan hasil $12 \%$ tidak sesuai.

\section{DAFTAR PUSTAKA}

[1] Badan Akreditasi Nasional Perguruan Tinggi (BAN-PT). 2011. Buku III Borang AIPT. BAN-PT: Jakarta.

[2] Badan Akreditasi Nasional Perguruan Tinggi (BAN-PT). 2011. Buku VI Matriks Penilaian Akreditasi Program Studi Sarjana. BAN-PT: Jakarta.

[3] Badan Akreditasi Nasional Perguruan Tinggi (BAN-PT). 2008. Buku VI Matriks Penilaian Akreditasi Program Studi Sarjana. BAN-PT: Jakarta.

[4] Bin Ladjamudin, Al bahra. 2005. Konsep Sistem Basis Data dan Implementasinya. Yogyakarta: Graha Ilmu.

[5] Departemen Pendidikan Nasional. 2002. Kamus Besar Bahasa Indonesia. Jakarta: Balai Pustaka. 
[6] Jogiyanto, HM, 2005, “Analisis dan Desain Sistem Informasi : Pendekatan Terstruktur Teori dan Praktik Aplikasi Bisnis". Yogyakarta: Andi.

[7] Peraturan Pemerintah Republik Indonesia Nomor 19 Tahun 2005 Standar Nasional Pendidikan. 16 Mei 2005. Lembaran Negara Republik Indonesia. Jakarta.

[8] Presman, Roger S. 1997. Rekayasa Perangkat Lunak Pendekatan Praktis. Yogyakarta: Buku Satu, Andi Offset.

[9] Romeo. 2003. Testing dan Implementasi Sistem Edisi 1. Surabaya: STIKOM.

[10] Sidharta, Lani, 1995. Pengantar Sistem Informasi Bisnis. Jakarta: PT. Elex Media Komputindo.
[11] Suhairi. 2010. Perancangan Sistem Informasi Manajemen Aset (Studi Kasus Pada Pt.Ciptakridatama). Jakarta : Universitas Gunadarma.

[12] Susilo, Franstia Wira Sukma. Rancang Bangun Aplikasi Sistem Informasi Manajemen Aset Perusahaan (Studi Kasus: Stikom Surabaya). http://download.portalgaruda.org/article.p hp?article $=120071 \&$ val $=5494$ diakses pada tanggal 19 Februari 2014 (18:25).

[13] Syahril. 2005. Manajemen Sarana dan Prasarana. Padang : UNP PRESS.

[14] Yaqin, M.Ainul. 2013. Analisis Pieces. http://yaqinov.wordpress.com/2013/ 10/16/analisis-pieces/diakses pada tanggal 20 Januari 2014 (15:23). 